\title{
Histopathological and Biochemical evaluations of the antidotal efficacy of Nigella sativa oil on organophosphate induced hepato-toxicity
}

\author{
Ajao MS. ${ }^{1}$, Abdussalam WA. ${ }^{1}$, *Imam A. ${ }^{1}$, Amin A. ${ }^{2}$, Ibrahim A. ${ }^{1}$, Adana MY. ${ }^{1}$, \\ Sulaimon FA. ${ }^{1}$, Atata JA. ${ }^{3}$
}

\begin{abstract}
Objective: The study was designed to investigate the effects of continuous exposure of dichlorvos (DDVP) on hepatic function and hepatic histomorphology, with the possible antidotal efficacy of Nigella sativa oil (NSO).
\end{abstract}

Methods: Twenty four Wistar rats were randomly divided into four groups, with each group comprising of six rats. The groups were labelled as Sunflower oil (SFO), DDVP, DDVP+NSO and NSO. After 14 days of treatments, blood samples were collected, centrifuged and levels of ALP (Alkaline phosphatase), ALT (Alanine aminotransferase), AST (Aspartate aminotransferase) and GGT ( $\gamma$-glutamyl-transferase) concentrations were estimated in the serum. The livers were removed and prepared for histopathological examinations and evaluation.

Results: The findings of the study shows significant increase in the serum concentration of ALT, ALP, AST and GGT with a marked distortion in the hepatic architecture in rats administered with DDVP. However, Nigella sativa oil (NSO) was observed to ameliorate the levels of impairment in the assessed hepatic function parameters and relatively restoration in the hepatic architecture in DDVP+NSO treated animals when compared to the control and group administered with DDVPonly.

Conclusion: The study concludes that impaired liver functions and histomorphological tissue distortions observed in the experimental rats following DDVP exposure were ameliorated following the administration of NSO.

Keywords: Nigella sativa, dichlorvos, antidotal effect, hepatotoxicity, liver function test

*Correspondence Author: Imam A., E-mail address: imam.a@ unilorin.edu.ng

${ }^{\mathrm{I}}$ Department of Anatomy, Faculty of Basic Medical Sciences, College of Health Sciences, University of Ilorin, Ilorin, Nigeria.

${ }^{2}$ Department of Physiology, Faculty of Basic Medical Sciences, College of Health Sciences, University of Ilorin, Ilorin, Nigeria.

${ }^{3}$ Department of Veterinary Pathology, Faculty of Veterinary Medicine, University of Ilorin, Ilorin, Nigeria.

Research Journal of Health Sciences subscribed to terms and conditions of Open Access publication. Articles are distributed under the terms of Creative Commons Licence (CC BY-NC-ND 4.0). (http://creativecommons.org/licences/by-nc-nd/4.0).

http://dx.doi.org/10.4314/rejhs.v5i1.3 


\title{
Evaluation histopathologique et biochimique de l'efficacité antidote de l'huile de Nigella sativa sur l'hépato-toxicité induite par les organophosphates
}

\author{
Ajao MS. ${ }^{1}$, Abdussalam WA. ${ }^{1},{ }^{*}$ Imam A. ${ }^{1}$, Amin A. ${ }^{2}$, Ibrahim A. ${ }^{1}$, Adana MY. ${ }^{1}$, \\ Sulaimon FA. ${ }^{,}$, Atata JA. ${ }^{3}$
}

\section{Resume}

Objectif: L'étude a été conçue pour étudier les effets de l'exposition continue du dichlorvos (DDVP) sur la fonction hépatique et l'histomorphologie hépatique, avec l'efficacité antidote possible de l'huile de Nigella sativa(NSO).

Méthodes: Vingt-quatre rats Wistar ont été répartis au hasard en quatre groupes, chaque groupe comprenant six rats. Les groupes ont été étiquetés comme huile de tournesol (SFO), DDVP, DDVP + NSO et NSO. Après 14 jours de traitement, des échantillons de sang ont été prélevés, centrifugés et des concentrations de ALP (phosphatase alcaline), ALT (Alanine aminotransférase), AST (aspartate aminotransférase) et GGT (y-glutamyl-transférase) ont été estimées dans le sérum. Les foies ont été retirés et préparés pour des examens histopathologiques et une évaluation.

Résultats: Les résultats de l'étude montrent une augmentation significative de la concentration sérique de ALT, ALP, AST et GGT avec une distorsion marquée dans l'architecture hépatique chez les rats administrés avec DDVP. Cependant, l'huile de Nigella sativa (NSO) a été observée pour améliorer les niveaux d'altération des paramètres de la fonction hépatique évaluée et relativement la restauration dans l'architecture hépatique chez les animaux traités par DDVP + NSO comparativement au témoin et au groupe administré uniquement avec le DDVP.

Conclusion: L'étude conclut que les fonctions hépatiques altérées et les distorsions tissulaires histomorphologiques observées chez les rats expérimentaux suite à l'exposition au DDVP ont été améliorées après l'administration de l'ONS.

Mots-clés: Nigella sativa, dichlorvos, effet antidote, hépatotoxicité, test de la fonction hépatique

\footnotetext{
* Correspondance Auteur: Imam A., E-mail address: imam.a@unilorin.edu.ng
}

${ }^{1}$ Department of Anatomy, Faculty of Basic Medical Sciences, College of Health Sciences, University of Ilorin, Ilorin, Nigeria.

${ }^{2}$ Department of Physiology, Faculty of Basic Medical Sciences, College of Health Sciences, University of Ilorin, Ilorin, Nigeria.

${ }^{3}$ Department of Veterinary Pathology, Faculty of Veterinary Medicine, University of Ilorin, Ilorin, Nigeria. 


\section{INTRODUCTION}

For centuries, pesticides and or insecticide are vital in agriculture to improve food production, eradicate insects and control disease vectors (1). Organophosphorus (OP) compounds are the most used insecticides, in both agriculture and household (2). Most insecticides, including the OPs have been implicated in severe environmental and health hazards (3-5), and their direct exposure to farm workers through residue in agricultural products and spillage on water sources remain the main source(s) of the accidental poisonings $(6,7)$, resulting in high motility especially in the developing world, due to inadequate management capacities (8).

Dichlorvos (DDVP) is a highly volatile organophosphate (9) with rapid absorption through the gastrointestinal (oral), respiratory tracts (inhalation) and skin (topical), and high bioavailability in the liver and kidney $(10,11)$. It's toxicity have been associated with irreversible acetycholineesterase inhibition leading to acetylcholine accumulation, with clinical signs and symptoms well characterized to include lacrimation, salivation, bronchoconstriction, anoxia, and severe cardiac disturbances (12). Although, treatment of OPs poisoning involved routine use of several antidotes including atropine and pralidoxime chloride, they are without unavoidable limitations (13). Therefore, research into finding alternative regimen in the management of OPs poisoning is crucial.

Medicinal plants have received high patronage, with an estimated $80 \%$ of the world population depending on herbal supplements, due to the growing perception of their safety and efficacy in the management of infections and other related diseases including hepatotoxicity $(14,15)$. Nigella sativa, also called black seed or black cumin (16), is a native of South and Southwest Asia and one of the most popular Ayurvedic medicines employed in the treatment of many diseases (17). The evidences of its therapeutic efficacies span decades of scientific literature and includes broncho-dilatation, immune-modulation (18), antibacterial (19), hypotension (20), anti-diabetic (21), hepatoprotective (22), gastro protective (23), antihistaminic and anti-oxidative $(24,25)$, neuroprotective $(26,27)$ and tumour suppressive $(28)$. Plants extracts are also used as memory enhancement $(29,30)$, infertility improvement in men (31) and efficacy in neurodegenerative diseases and disorders $(32,33)$.

The aim of the present study was investigate the effects of continuous exposure of dichlorvos
(DDVP) on hepatic function and hepatic histomorphology, with the possible antidotal effect of Nigella sativa oil (NSO).

\section{MATERIALS AND METHODS Chemicals and Drugs}

Dichlorvos (purity 98\%) and analytical graded sunflower oil were purchased from an Agrochemical store and local store respectively in Ilorin, Nigeria. The black seed oil (100\% pure natural oil) was obtained from Masrawarda, Kingdom of Saudi Arabia.

\section{Animal care}

Twenty four adult male Wistar rats weighing between 120 and $180 \mathrm{~g}$ were obtained from the University of Ilorin Biological garden, Ilorin. They were housed in plastic cages and fed with standard laboratory diet and water ad libitum in the animal holding unit of the Faculty of Basic Medical Sciences, College of Health Sciences, University of Ilorin, Ilorin. The rats were exposed to a 12 hours light/dark cycle at room temperature for 7 days before the commencement of the experiments. All rats were handled in accordance with the standard guide for the care and use of laboratory animals.

\section{Treatments schedule}

The rats were randomly distributed into four groups $(n=6)$ as follows:

Group 1: were given sun flower oil $(1 \mathrm{ml} / \mathrm{kg}$ orally) daily for 14 days

Group 2: were given sun flower oil ( $1 \mathrm{ml} / \mathrm{kg}$ oral) for 7 days followed by DDVP $(8.8 \mathrm{mg} / \mathrm{kg} /$ day orally) (34) for another 7 days

Group 3: were given DDVP $(8.8 \mathrm{mg} / \mathrm{kg} /$ day orally) for 7 days then followed by NSO $(1 \mathrm{ml} / \mathrm{kg}$ orally) daily for another 7 days

Group 4: were given sun flower oil ( $1 \mathrm{ml} / \mathrm{kg}$ oral) daily for 7 days thereafter NSO (1 ml/kg orally) $(35,36)$ daily for another 7 days

All procedures were scheduled and carried out during the early phase of the day between 06:30 and 09:00 hours, and treatments were given for fourteen consecutive days.

\section{Biochemical evaluation}

At the end of the experiments, blood samples were collected from the heart into sterile tubes, centrifuged at $3500 \mathrm{rpm}$ for $20 \mathrm{~min}$, and the serum were collected into other sterile tubes and 
properly marked according to the groups. The livers were removed immediately and washed with sodium phosphate buffer ( $\mathrm{pH}$ 7.2). ALP (alkaline phosphatase), ALT (alanine aminotransferase), AST (aspartate aminotransferase) and GGT ( $\gamma$-glutamyltransferase) were assessed in the serum using commercially available enzymatic-kinetic kit (SpinReact-BECGMAN, Germany) and analyzed through autoanalyzer (Bayer ope-RA).

\section{Histological study}

Liver tissues were fixed in $10 \%$ neutralbuffered formalin and embedded in paraffin. Sections of $5 \mu \mathrm{m}$ thickness were attached to slides, deparaffinized and stained with hematoxylin and eosin (H\&E) for light microscopic examination.

\section{Statistical analysis}

Data from the serum ALT, ALP, AST and

GGT levels were subjected to analysis of variance (ANOVA) and Bonferroni post-hoc test using Graph Pad Prism (Version 16). Confidence interval of $95 \%$ ( $\mathrm{P}$ value $\geq 0.05$ ) was considered to be significant.

\section{RESULTS \\ Effect of DDVP and NSO on liver function parameters \\ The administration of DDVP only to the} rats caused a significant $(\mathrm{P} \leq 0.05)$ rise in the concentration levels of AST, ALT, ALP and GGT when compared to the control group with the treatment groups (Table 1). In the groups with post administration of NSO, the findings in the NSO group compares favourably with the control and those with DDVP treated rats (Table 1).

\section{Effect of DDVP and NSO on hepatic histomorphology}

DDVP administered animals showed degeneration in the hepatocytes $(\mathrm{H})$, dilatation of sinusoids $(\mathrm{S})$, and inflammatory like cellular infiltration in the distorted hepatocytes when compared to the control. The portal triad (hepatic artery (HA), portal vein (PV) and interlobular bile ducts (IBD)) appeared normal with minimal distortion across the groups. However, there were no significant differences between the control and the post treated groups (Figures 1).

\section{DISCUSSION}

Accidental poisoning with organophosphate has been on the rise especially in the developing worlds in recent years, resulting in increasing rate of morbidity and mortality. The poor and inadequate health facilities complicates the situation and often results in poor quality of life (37). These poisoning incidences that are mostly associated with Ops are mostly due to residues in food substances such maize, wheat, vegetables, apples and orange $(38,39)$ and contaminated water. The liver is the major site of xenobiotic metabolism and first pass metabolism for most drugs and chemicals, hence, hepatotoxicity would be central to any poisoning especially when ingested into the body. The hepatic function test is vital in any toxicity diagnosis. The activities of ALT, AST and ALP enzymes are often considered sensitive biomarkers which may directly demonstrate the extent to which hepatic damage may have occurred and or level of it toxicity $(40,41)$. Pesticide induced hepatotoxicity especially those arising from OP are of growing concern (42) and the need to find agents that can mitigate the situation becomes expedient at this particular time since the nation is moving toward agriculture and these may increase the rate of accidental poisoning.

The findings of the present study demonstrated that acute DDVP exposure provoked a marked elevation in serum concentrations of AST, ALT, ALP and GGT activities which are used as predictive indices of hepatocellular damage or hepatotoxicity. The present findings were strengthened by the earlier studies involving the use of DDVP and other Ops compounds which shows elevation in the serum concentrations of the liver enzymes as indicated above $(43,44)$. The elevation observed in the study activities of the enzymes could be attributable to the response of the hepatocytes from their cytoplasm in response to the inflammatory activities that follow through hepatic assault recovery stage. It must be noted that previous studies have reported similar findings where they observed increased hepatic function with massive release of these hepatic function enzymes into circulation (45) with a loss of functional integrity of the hepatic membrane (46). It is pertinent to note that exponential rise in ALP concentration along with GGT are strong indicators of bile duct obstruction and liver damage (47).

Although $1 / 10$ of the oral $\mathrm{LD}_{50}(80 \mathrm{mg} / \mathrm{kg}$ in rats) (48) was administered in the present study; a marked pathological changes were observed in the hepatic function enzymes and hepatic morphology. The histopathological alterations reported in this study are suggestive of degeneration and necrosis in the hepatocytes, 
cellular inflammatory responses leading to a sustained leakage of liver enzymes, and a burst in their level in the serum as seen in this study. The burden of OPs induced hepatotoxicity is not limited to its poisoning, but includes the limitations in the use of the available antidote (13). Nigella sativa used in the present study was observed to meliorate the hepatotoxicity activities of DDVP, by reducing the busted levels of the hepatic function enzymes (ALT, AST, ALP and GGT) in the rats that are exposed to only NSO and in those with prior exposure to DDVP. These findings were strengthened by similar reports of NSO and its activities. The active agent that was found in NSO was Thymoquinone has been to shown to mitigate the activities OPs and other compounds that maybe involved in the inducement of hepatotoxicity and toxicity of other systems $(35,49,50)$, and similar toxic substances $(51,52)$.

The hepato-protective effects of NSO in this study can be greatly attributed to its Thymoquinone constituent (53-55), since it has been reported to exhibit cerebral, renal, liver, and cardiac protective effects against many xenobiotic (56). Though there is a rapid turnover of hepatic cells especially during hepatic injuries, these activities may be further elevated with the presence of NSO which could serve in the positive modulation of the hepatic cells and creation of an enable environment which is a key factor during regeneration. Therefore, since the activities of NSO against DDVP induced hepatotoxicity is apparent in this study, it may be a viable alternative antidote in the management of OPs poisoning, especially, Dichlorvos. Hence, in research for novel therapeutic antidotes to OPs poisoning, NSO, which is highly valued as a traditional regimen, with tested efficacy in many diseases is highly recommended for use.

\section{CONCLUSION}

In the present study, experimental group was exposed to two dosage of the chemical substance. Liver enzymes and hematologic constituents were used as important bio-markers for detection of hepatotoxic and hematotoxic nature of this pesticide. Four serum hepatic marker enzymes (ALT, AST, LDH, and ALP) were evaluated for hepatotoxicity. According to the results, DIC caused a signi? cant increase in the AST, ALT, LDH, and ALP activities in rats treated with DIC in comparison to those of controls. The reasons for such effect of DIC are not understood at present certainly. However, it is known that several of soluble enzymes of blood serum such as these enzymes have been considered as indicators of the hepatic dysfunction and damage.

Conflict of interest: The authors declare no conflicts of interest.

\section{REFERENCES}

1. Prakasam A., Sethupathy S., Lalitha S. Plasma and RBCs antioxidant status in occupational male pesticide sprayers. Clin. Chim. Acta. 2001; 310: 107-112.

2. Al-Saleh I.A. Pesticides: a review article. J. Environ. Toxicol. Oncol. 1994; 13: 151-161.

3. Tuzmen N., Candan N., Kaya E., Demiryas N. Biochemical effects of chlorpyrifos and deltamethrin on altered antioxidative defense mechanisms and lipid peroxidation in rat liver. Cell Biochem. Funct. 2008; 26: 119-124.

4. Heikal T.M., Soliman, M.S. Effect of fish oil supplementation on brain DNA damage and hepatic oxidant/antioxidant status in dimethoatetreated rats. J. Egyptian Soci. Toxicol. 2010; 42: 1-9.

5. Heikal T.M, Ghanem H.Z, Soliman M.S. Protective effect of green tea extracts against dimethoate induced DNA damage antioxidant/antioxidant status in male rats. Biohealth. Sci. Bull. 2011; 3(1): 1-11.

6. Maroni M., Fanetti A.C., Metruccio F. Risk assessment and management of occupational exposure to pesticides in agriculture. Med Lav 2006; 97: 430-437.

7. Soares W.L., Porto M.F.D. Estimating the social cost of pesticide use: An assessment from acute poisoning in Brazil. Ecol Econ 2009; 68: 27212728.

8. Eddleston M., Juszczak E., Buckley N.A., Senarathna L., Mohamed F., Dissanayake W., Hittarage A., Azher S., Jeganathan K., Jayamanne S., Sheriff M.H.R., Warrell D.A. Multiple-dose activated charcoal in acute selfpoisoning: a randomised controlled trial. Lancet 2008; 371: 579-587

9. Carpenter M.J., Ware G.W. Defending Pesticides in Litigation, 14th Ed. West- Thomson, Fresno California, 2004; Pp. 763.

10. Durkin P.R., Follansbee M.H. Control/eradication agents for the gypsy moth human, health and ecological risk assessment for DDVP (Dichlorvos). Syracuse Research Corporation, 301 Plainfield Road, Suite 350, Syracuse, New York 13212. Requisition 2004; No.: 43-3187-1-0269.

11. Chemicals Evaluation and Research Institute (CERI), Japan. Hazard assessment report on 
Dimethyl2,2-dichlorovinyl phosphate. CAS 2007; no. 62-73-7.

12. Lotti M. The pathogenesis of organophosphate poly neuropathy. Toxicology 1992; 21, 465-483.

13. Yadav P., Jadhav S.E., Kumar V., Kaul K.K., Pant S.C., Flora S.J.S. Protective efficacy of 2PAMCl, atropine and curcumin against dichlorvos induced toxicity in rats. Interdisc Toxicol. 2012; 5(1):1-8

14. Ogbera A.O., Dada O., Adeyeye F., Jewo P.I. Complementary and alternative medicineuse in diabetes mellitus. West Afr J Med 2010; 29: 158162.

15. Krishnan N., Muthukrishnan S. Effect of Nigella sativa seed extract on carbon tetrachlorideinduced hepatotoxicity in rats. Journal of Acute Medicine 2012; 2.107e113

16. Heiss A. "The oldest evidence of Nigella damascena L. (Ranunculaceae) and its possible introduction to central Europe". Vegetation History and Archaeobotany 2005; 14 (4): 562-570.

17. Goreja W.G. Black seed: nature's miracle remedy. New York, NY: Amazing Herbs Press 2003

18. El-Kadi A., Kandil O. The black seed (Nigella sativa) and immunity: it effect on human T cell subset. Fed Proc 1987; 46: 1222-1226

19. Hanafy M.S., Hatem M.E. Studies on the antimicrobial activity of the Nigella Sativa seed (Black Cumin).J Ethnopharmacol, 1991; 34: 275-278.

20. Zaoui A., Cherrah Y., Lacaille-Dubois M.A., Settaf A., Amarouch H., Hassar M. Diuretic and hypotensive effects of Nigella sativa in the spontaneously hypertensive rat. Therapie, 2000; 55: 379-382.

21. Kanter M., Coskun O., Korkmaz A., Oter S. Effects of Nigella sativa on oxidative stress and beta-cell damage in streptozotocin-induced diabetic rats. Anat Rec A Discov Mol Cell Evol Biol 2004; 279: 685-691.

22. Kanter M., Coskun O., Budancamanak M. Hepatoprotective effects of Nigella sativa $\mathrm{L}$ and Urticadioica L on lipid peroxidation, antioxidant enzyme systems and liver enzymes in carbon tetrachloride-treated rats. World J Gastroenterol 2005a; 11: 6684-6688.

23. Kanter M., Demir H., Karakaya C., Ozbek H. Gastro protective activity of Nigella sativa $\mathrm{L}$ oil and its constituent, thymoquinone against acute alcohol induced gastric mucosal injury in rats. World J Gastroenterol 2005b; 11: 6662-6666.

24. Kanter M., Coskun O., Uysal H. The antioxidative and antihistaminic effect of Nigella sativa and its major constituent, thymoquinone on ethanol-induced gastric mucosal damage.
Arch Toxicol 2006a; 80: 217-224.

25. Badary O.A., Taha R.A., Gamal El-Din A.M., Abdel-Wahab M.H. Thymoquinone is a potent superoxide anion scavenger. Drug Chem Toxicol 2003; 26: 87-98.

26. Kanter M., Coskun O., Kalayci M., Buyukbas S, Cagavi F. Neuroprotective effects of Nigella sativa on experimental spinal cord injury in rats. Hum Exp Toxicol 2006b; 25: 127-133.

27. Javanbakht J., Hobbenaghi R., Hosseini E., Bahrami A.M., Khadivar F., Fathi S., Hassan M.A. Histopathological investigation of neuroprotective effects of Nigella sativa on motor neurons anterior horn spinal cord after sciatic nerve crush in rats. Pathol Biol. 2003; 61:250-253.

28. Torres M.P., Ponnusamy M.P., Chakraborty S., Smith L.M., Das S., Arafat H.A., Batra S.K. Effects of thymoquinone in the expression of mucin 4 in pancreatic cancer cells: implications for the development of novel cancer therapies. Mol Cancer Ther 2010; 9: 1419- 1431.

29. Imam A., Ajao M.S., Ajibola M.I., Amin A., Abdulmajeed A.I., Lawal A.Z., Alli-Oluwafuyi A., Akinola O.B., Oyewopo A.O., Olajide O.J., Adana M.Y. Black seed oil reversed scopolamine-induced Alzheimer and corticohippocampal neural alterations in male Wistar rats. Bull - Fac. of Pharm, Cairo Univ. 2016; http://dx.doi.org/10.1016/j.bfopcu.2015.12.005

30. Farimah B., Mahmoud H., Farzaneh V., Mohammad N.S., Mohammad S. Feeding of Nigella sativa during neonatal and juvenile growth improves learning and memory of rats. $\mathbf{J}$ Trad. Compl Med. 2016; 6:146-152

31. Kolahdooz M., Nasri S., Modarres S.Z., Kianbakht S., Huseini H.F. Effects of Nigella sativa L.seed oil on abnormal semen quality in infertile men: A randomized, double blind, placebo controlled clinical trial. Phytomedicine. 2014; 21:901-905.

32. Dariani S., Baluchnejadmojarad T., Roghani M. Thymoquinone Attenuates Astrogliosis, Neurodegeneration, Mossy Fiber Sprouting, and Oxidative Stress in a Model of Temporal Lobe Epilepsy. J Mol. Neurosci. 2013; 51(3):679-86. doi: 10.1007/s12031-013-0043-3

33. Alhebshi A.H., Gotoh M., Suzuki I. Thymoquinone protects cultured rat primary neurons against amyloid $\beta$-induced neurotoxicity. Biochem. Biophys Res Commun. 2013; 19: 433(4):362-7.

34. Sharma P., Singh R. Dichlorvos and lindane induced oxidative stress in rat brain: Protective effects of ginger. Pharmacognosy Research. 2012; 4(1):27-32. doi:10.4103/09748490.91031 . 
35. Atef M.A., Wafa'a A.A. Preventive Effects of Black Seed (Nigella Sativa) Extract on Sprague Dawley Rats Exposed to Diazinon. Aus J. Bas App Sci. 2010; 4(5): 957-968

36. Nahed S.K., Bassant A.E. Prophylactic effect of green tea and Nigella sativa extracts against fenitrothion-induced toxicity in rat parotid gland. Arch Oral Biology. 2011; 56(11):1339-1346

37. Fariba T., Gholamhassan V., Mohammad A. Ali A.M. A Comparative Study of the Quality of Life, Depression, Anxiety and Stress in Farmers Exposed to Organophosphate Pesticides with those in a Control Group. J. Chem Health Risks. 2016; 6(2): 143-151

38. Davies M.S., Boniface M., Gibson S. Determination of dichlorvos residue levels in vegetables sold in Lusaka, Zambia. Pan Afr. Med J . $\quad 2016 ; \quad 23: 113$ doi:10.11604/pamj.2016.23.113.8211

39. Rashmikaa S., Manju B.G., Bhat L.R., Noel N., Swaminathan S., Uma M.K., John B.B.R. Simultaneous detection of mono crotophos and dichlorvos in orange samples using acetycholineesterase-zinc oxide modified platinum electrode with linear regression calibration. Sensors and Actuators B. Chemical. 2016; 230: 306-313

40. El-Demerdash F.M. Antioxidant effect of vitamin $\mathrm{E}$ and selenium on lipid peroxidation, enzyme activities and biochemical parameters in rats exposed to aluminium. J. Trace Elem. Med. Biol. 2004; 18: 113-121.

41. Stockham S.L., Scott M.A. Fundamentals of Veterinary Clinical Pathology. Iowa State: University Press Ames 2002; p. 434-459.

42. Michael A.G., Nicholas J.L. Organophosphorus pesticides. In Handbook of Pesticides Toxicology", eds. Wayland J. Hayes, Jr. and Edward R. Laws, Jr. 1991; 917. San Diego: Academic Press Inc.

43. Ayse O., Zekiye S., Yusuf K. Dichlorvos-induced hepatotoxicity in rats and the protective effects of vitamins $\mathrm{C}$ and E. Environmental Toxicology and Pharmacology. 2008; 26 (3): 355-361

44. Kalender S., Ogutcu A., Uzunhisarcikli M., Acikgoz F., Durak D., Ulusoy Y., Kalender Y. Diazinon-induced hepatotoxicity and protective effect of vitamin $\mathrm{E}$ on some biochemical indices and ultrastructural changes. Toxicology. 2005; 211: 197-206.

45. Kuzu N., Metin K., Ferda D.A., Akdemir F., Orhan C., Yalniz M., Ozercan I.H., Kazim S., Bahcecioglu I.H. Protective role of genistein in acute liver damage induced by carbon tetrachloride. Mediators Inflamm. 2007; 1-6.

46. Pari L., Prasath A. Efficacy of caffeic acid in preventing nickel induced oxidative damage in liver of rats. Chem. Biol. Interact 2008; 173 : 77-83.

47. Akhtar N., Srivastava M.K., Raizada R.B. Assessment of chlorpyrifos toxicity on certain organs in rat, Rattus norvegicus. J. Environ. Biol. 2009; 30(6):1047-1053.

48. Okamura A., Kamijima M., Shibata E., Ohtani K., Takagi K., Ueyama J., Watanabe Y., Omura M., Wang H., Ichihara G., Kondo T., Nakajima T. A comprehensive evaluation of the testicular toxicity of dichlorvos in Wistar rats. Toxicology, 2005; 213, pp. 129-137

49. Mahmood A.E., Thanaa A.E., Ashraf M.E., Mohammed A.H. Potential hepato-protective effects of vitamin $\mathrm{E}$ and Nigella sativa oil on hepatotoxicity induced by chronic exposure to malathion in human and male albino rats, Toxicological \& Environmental Chemistry $2010 ; 92: 2,391-407$, D O I : 10.1080/02772240902955719

50. Rachid M., Mokhtar I.Y., Francesca M., Alberto M. Protective role of Nigella sativa oil against reproductive toxicity, hormonal alterations, and oxidative damage induced by chlorpyrifos in male rats. Toxicology and Industrial Health. 2014; 32(7), pp. 1266-1277

51. Ilhan N., Sec sin D. Protective effect of Nigella sativa seeds on CCL4-induced hepatotoxicity. F.U: Sag `lik Bil. Dergisi. 2005; 19: 175-9

52. Hagag A.A., Elaal A.M.A., Elsheik A., Elzamarany E.A. Protective Effect of Nigella sativa Oil against Methotrexate Induced Hepatotoxicity in Children with Acute Lymphoblastic Leukemia. J Leuk (Los Angel). 2013; 1:123. doi: 10.4172/2329-6917.1000123

53. Badary O.A. Thymoquinone attenuates ifosfamide-induced fanconi syndrome in rats and enhances its antitumor activity in mice. $J$. Ethnopharmacol. 1999; vol. 67, 1999, p. 135142.

54. El-Daly E.S. Protective effect of cysteine and vitamin E Crocus sativus and Nigella sativa extracts on cisplatin-induced toxicity in rats. $J$. Pharm. Belo. 1998; vol. 53, 1998, p. 87-95

55. Zaoui A.C., Mahassini N.Y., Alaoui K.A., Hassar H.M. Acute and chronic toxicity of Nigella sativa fixed oil, Phytomedicine. 2002; vol.9, p. 69-74.

56. Mohamadin A.M., Sheikh B., Abd El-Aal A.A., et al. Protective effects of Nigella sativa oil on propoxur induced toxicity and oxidative stress in rat brain regions. Pesticide Biochemistry and Physiology. 2010; 98: 128-134 
Table 1: The serum levels of liver function parameters in rats given SFO, DDVP, DDVP+NSO and NSO

\begin{tabular}{lllrl}
\hline Groups & AST (U/L) & ALT (U/L) & ALP (U/L) & GGT (U/L) \\
SFO & $11.7 \pm 1.09$ & $5.1 \pm 1.3$ & $38.51 \pm 3.29$ & $14.55 \pm 0.99$ \\
DDVP & $22.1 \pm 1.7^{* *}$ & $11.2 \pm 1.3^{* *}$ & $89.38 \pm 2.13^{* *}$ & $25.78 \pm 4.45^{* *}$ \\
DDVP+NSO & $5.2 \pm 1.1^{*}$ & $7.1 \pm 0.6$ & $79.45 \pm 3.24^{* *}$ & $24.92 \pm 0.28^{* *}$ \\
NSO & $6.8 \pm 2.2^{*}$ & $7.7 \pm 0.9$ & $34.02 \pm 1.78^{*}$ & $9.52 \pm 0.36$ \\
\hline
\end{tabular}

Data are presented as mean \pm SEM. $(\mathrm{n}=6)$. The double $\left({ }^{* *}\right)$ asterisk indicate a significant $(\mathrm{P}=0.05)$ increase when compared with the control, while the single $\left({ }^{*}\right)$ asterisk indicate a significant $(\mathrm{P}=0.05)$ reduction when compared with the DDVP treated animals. ANOVA with Bonfferoni multiple comparisons test were employed.

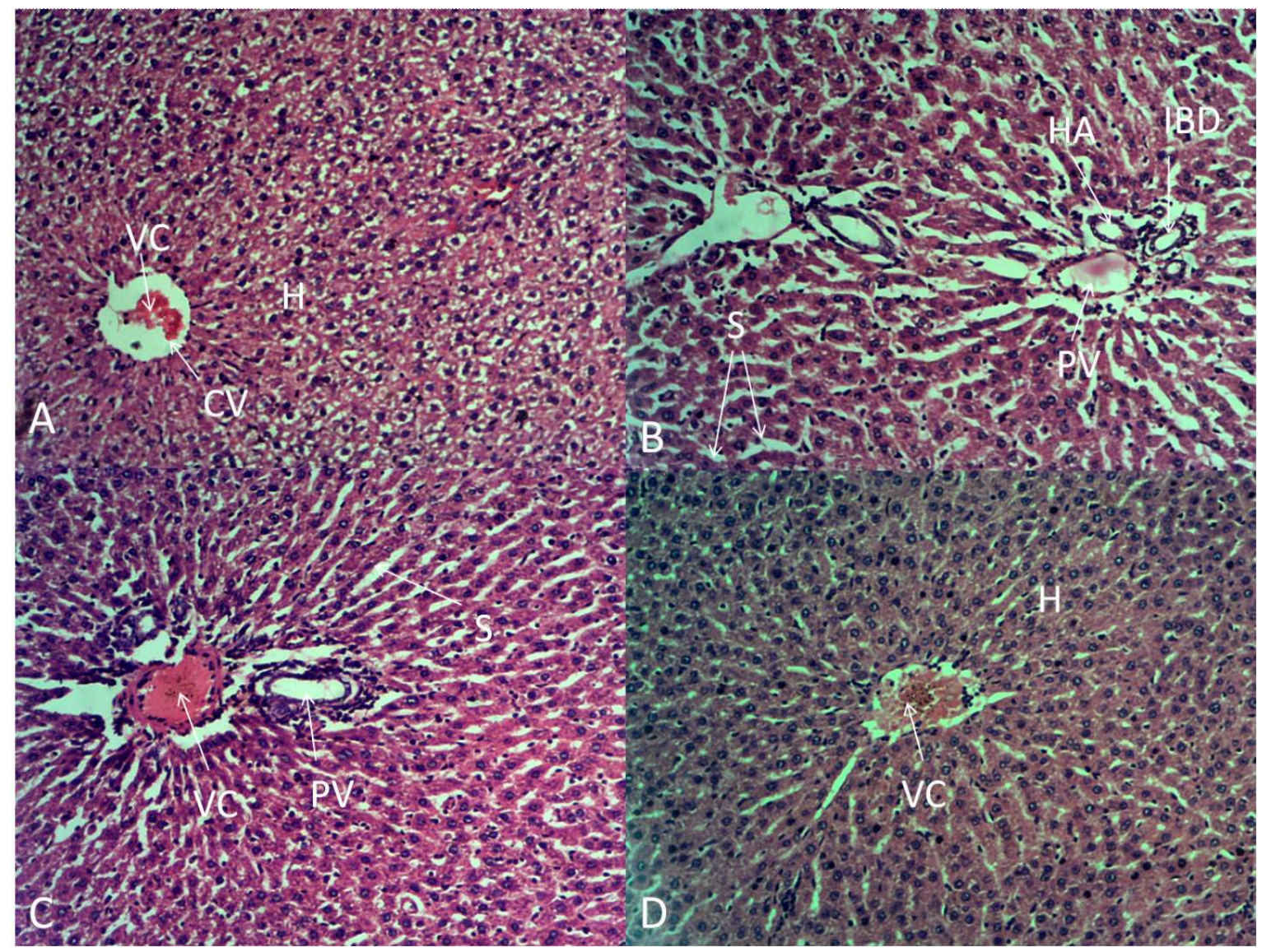

Figure 1: Showing the histoarchitecture of the liver of rats following exposures to SFO (A), DDVP (B), DDVP+NSO (C) and NSO (D) respectively. Revealing the Sinusoids (S); Hepatocytes (H); Portal vein (PV); Central vein (CV); Vascular congestion (VC); Hepatic artery (HA); and Inter biliary duct (IBD). Haematoxylin and Eosin (H\&E) X100 